DOI: 10.17951/bc.2020.5.113-122

\begin{tabular}{lcr}
\hline & ANNALES \\
& UNIVERSITATIS MARIAE CURIE-SKLODOWSKA & \\
LUBLIN - POLONIA & \\
VOL.V & SECTIO M & 2020 \\
\hline
\end{tabular}

\author{
Beata Varga \\ University of Szeged, Hungary \\ varga.bea@hist.u-szeged.hu \\ ORCID ID: //orcid.org/0000-0001-7244-0783
}

\title{
Divided Ukrainian Historical Remembrance
}

This text analyses the reasons for the formation of the divided Ukrainian historical remembrance. Dis-unification of Ukrainian territories within the framework of a sovereign state practically lasted for long centuries, with singular Ukrainian regions being part of various states of differing cultural and political and power structure during that period. As a result, all this has divided Ukrainian history and hindered endeavours for unification. Moreover, it has seriously contributed to the phenomenon of different regions being formed in "Ukrainian lands"1 with significantly diverse characteristics, both in the past and nowadays.

\section{Divided Ukraine - "divided history"}

During the long historical process of the Periphery ${ }^{2}$, that is Ukraine, up to the formation of the sovereign Ukrainian state, Ukrainian territories had become the double, then triple periphery of various power spheres ${ }^{3}$. Until the middle of the 17th century, the Polish-Lithuanian authority had a major impact on

1 For lack of a continuous Ukrainian statehood, the concept of "Ukrainian lands" has been accepted in popular belief countrywide, furthermore, as a proof to justify the continuity of their national history, Ukrainians emphasize the continuity of Ukrainian-inhabited territories.

2 As regards the name of Ukraine, it first appeared in the 13th century, and referred to the region ranging from the Eastern slopes of the Carpathian Mountains to the River Don.

3 D. Karácsonyi, A kelet-európai sztyep és a magyar Alföld mint frontier-területek. Földrajzi értesitő. LVII. 1-2. füzet 2008. p.191. 
Ukrainian history, however, even after that, Polish-Ukrainian relations remained predominant up until 1939-1945. The Treaty of Pereyaslav ${ }^{4}$ in 1654, for example, enabled Ukraine to replace Polish-Lithuanian control with a Russian bond, yet, in accordance with the 1667 Truce of Andrusovo concluding the Russian-Polish War fought for the possession of Ukrainian lands, Western Ukraine was temporarily returned to the Polish-Lithuanian state. As a consequence of Poland's division in 1772-1795, the territory of Ukraine was shared between the Romanov and Habsburg dynasties ${ }^{5}$, whereas lands over the Carpathians had been part of Hungary and the Habsburgs since the Middle Ages. As for Southern Ukraine, with the Crimean Peninsula as its integral part, it was under Ottoman rule until the end of the 18th century, then, due to the successful Russo-Turkish Wars ${ }^{6}$, the Russian Empire extended its borders to the Black Sea coastline.

\section{Russian “versus" Ukrainian historiography}

The creation of a sense of uniform identity had always played a decisive role during the Ukrainian people's efforts for the establishment of a state, with a particular emphasis put on "national history". Considering that in the case of Ukraine we cannot talk about a state history in a general sense, therefore, the history of Ukrainians includes their specific historical and political experiences obtained in various periods and states?. As regards the Central and Eastern European region, present day Ukrainian national self-determination has been gradually formed by political events and social processes during the past 300 years. Still, the collection of Ukrainian regions of different development levels based on an ethnolinguistic principle into a unitary state could only be achieved as a result of the geopolitics of the 20th century. In addition, one must highlight the fact that in Ukrainian, the word "nacija" standing for nation, means a group of people linked by language and culture, yet referring to individuals not exclusively with a sovereign state. ${ }^{8}$

4 In 1654, the official denomination of the Hetmanate formed from territories voluntarily joining Russia eventually became the Zaporizhian Had, which term simultaneously denoted the Cossack troops of 60,000 in the service of the Romanovs, as well as the administrative system of Ukraine relying on the Cossack regiments.

5 From the 1780s onwards, unti the beginning of the 20th century, two powers held possession of the territory of Ukraine: approximately $80 \%$ belonged to the Russian Empire, while $20 \%$ (Galicia) was owned by the Habsburg Monarchy.

${ }^{6}$ As a result of the two Russo-Turkish Wars (1768-74 and 1787-92), the Northern coastline of the Black Sea was annexed to the Russian Empire.

7 A. Bocskor Medvecz, Nacionalizmus és történetírás. Az ukrán történelemformálás hatása a nemzetté válás folyamatában. In: Acta Beregsasiensis. VIII. 2. 2009. p. 17.

8 Sz. Jekelcsik, Ukrajna története- Egy Modern Nemzet születése. Kairosz, Budapest 2014. p. 23. 
As per the "traditional scheme" of Russian historiography, Moscuvite Russia, gaining shape since the 15th century, is to be considered as the exclusive successor of the Kievan Rus', while Ukrainian lands were named "Western-Russian" territories, which never ceased to aim at keeping their "Russian identity" even within the "Polish-Lithuanian" alliance. In truth, the history of the Ukrainians was regarded as an inseparable part of Russian history by Russian historian tradition, claiming that the "little Russians" are in fact a people lacking sovereign statehood - a subspecies of Russian ethnicity. ${ }^{9}$ As perceived by "pan-Russian" historians, Ukraine's peculiar national characteristics simply did not exist, moreover, due to the political "immaturity", in their judgement, a Ukrainian state could not stand a chance at all in Eastern Europe. Imperial Russian historiography regards the Kievan Rus', which may very well be considered as an organic part of Ukrainian history, the age of the Hetmanate (1654-1764), as well as the integration of the Northern coastline of the Black Sea into the Russian Empire exclusively as a glorious period of Russian civilization.

From 1991 onwards, in the course of the Ukrainian national identity building process it has become vital for contemporary Ukrainian politics to draw up "useable" historical narratives, during which the perpetual emphasizing of nation state sovereignty has gained positive emotional and political elements, ${ }^{10}$ thus, at the same time legitimizing the mere existence of the young Ukrainian state. Research and education of its national history played a significant role in the growth of Ukrainian identity, in addition, the call for making the past glorious and may it have continuity! had a vital role. In order to create their own "national history", Ukrainian historians were expected to prove that the Ukrainian people are at the disposal of their "own" continuous history, originated in its ancient roots. Consequently, one needed to, with sound arguments, historically support their statement claiming that the history of Ukrainians was constantly evolving between the 9th and 19th centuries regardless of the fact that in specific eras some parts of Ukrainian "lands" fell under the jurisdiction of the Polish and Lithuanian states, the Russian, Turkish and Hapsburg Empires.

${ }^{9}$ N. M., Karamzin, Istoriya gosudarstva rossiyskogo. The publication of I. Einernling, St. Petersburg 1842-1843. VI. pp. 5-6.; N. G. Ustryalov, Russkaya istoriya. Tip-ya ekspeditsii zagotovleniya gos., St. Petersburg 1839. p. 16; Pogodin, M. P., Issledovaniya, zamechanyia i lekciyi o russkoy istoriyi. Universitetskaya tipografiya, Moskva 1856. pp. 425-428.

${ }^{10}$ F. Glatz, Regionális történetszemlélet Közép-Kelet-Európában. In: Történelmi Szemle 43 (1-2). 2001. 100-101. 
To begin with, as a starting point we must take into account the book titled Istoria Russov ili i Maloy Rossii ${ }^{11}$, it being an integral part of 18 th century historiography, a fundamental work introducing the expectations of Cossack leaders and Ukrainian nobility to the Tsarist government, the study of which has exerted a major impact on almost all historians of the age and later adaptations, too. The author of this book formulated the thesis stating that in fact Ukraine has never been invaded, since Ukrainians always entered into alliances with other states voluntarily, being free and equal players, thus Ukraine has a natural, moral and historical right for sovereign political development. Although moderately, the notion of independence has been outlined in this very train of thought, which might refer to the trend of the Ukrainian elite gradually becoming more and more Russian since the end of the 18th century, yet not abandoning their endeavours for sovereign statehood.

Written at the end of the 18th and at the beginning of the 19th century, most Ukrainian historical works ${ }^{12}$ include predominantly subservient views only, conforming to Russian sovereignty, yet, aiming at changing the "pan-Russian" narrative to the extent that resulted a more graceful position for the Ukrainian people in the traditional historical scheme. Books and studies written in the era demonstrate deep localism and sound respect for the Ukrainian historical past, however, all of them highlight the belief that Ukraine is a natural and organic part of the Russian Empire.

During the late 19th century, Mykhailo Hrushevskyi, "the father of Ukrainian national history" ${ }^{\prime \prime}$, and first president of Ukraine ${ }^{14}$, worded the idea in his works that Ukraine indeed differs from Russia in many respects, including its language, culture, history and political traditions. In fact it was not until the early 1900s that historians sensed the urge to "create" a Ukrainian "national" history that hence forward forms a crucial part of national identity that was brought to life

${ }^{11}$ G. Kony'ssky`j, Istoriya Rusov ili Maloy Rossiyi. Universitetskaya tipografiya, Moskva 1846. pp. 209-229.

${ }^{12}$ A. I. Rigelman, Letopisnoye povestvovanye o Maloy Rossiyi i jejo narode a kozakakh voobse. Universitetskaya tipografiya, Moskva, 1847. p. 173.; D. N. Bantysh-Kamenskij, Istoriya Maloj Rossiyi ot vodvoreniya slavyan v cej strane do unichtozheniya getmanstva. Juzhno-russkoe knigoizd-vo FA. Johanson, Moskva1903. pp. 205-208.; N. A. Markevitch, Istoriya Malorossiyi. Tip. Avgusta Semena, Moskva 1842. II. pp. 167-168.

${ }^{13}$ B. Varga, M. Sz. Hrusevszkij, az "ukrán nemzeti történetírás atyja" In: Acta Universitatis. Szegediensis. 134 (2012) pp. 9-21.

${ }^{14}$ On 6 November, 1917, the Central Council of Ukraine issued its III. Universal, headed by President Hrushevskyi, it proclaimed the independence of the Ukrainian People's Republic. However, at the same time, it accepted maintenance of unity with the soon-to-be-established Russian Federation. 
not only by demand, but, in quoting Hrushevskyi ${ }^{15}$, through honour as well. The outstanding statesman and historian voiced his opinion that 19th century Ukraine must be considered a conglomerate of various ethnic, geographic and historical regions, having relatively diverse regional historic identity. Moreover, he reckoned that in the relations of the Russian and the Ukrainian people, the following problems had emerged and were brought to the forefront throughout history: 1. ethnic distinction and identification of the two peoples; 2. the issue of political and cultural heritage regarding the Kievan Rus'; 3. the problem of Russian and Ukrainian statehood, that is whether Ukrainians have a glorious past and whether they have the right to establish a sovereign state. As opposed to traditional Russian patterns, Hrushevskyi outlined several decisive moments of Ukrainian history, meaning that 1 . Ukrainians, as a separate nation have already existed since the early Middle Ages - furthermore, they had laid down the foundations of a sovereign state within the framework of the Kievan Rus', 2. it is neither the Vladimir-Suzdalian Rus nor the Grand Duchy of Moscow that is to be considered as the political successor of the Kievan Rus', but the Principality of Galicia-Volhynia, which later gradually lost its independence in the 14th century and integrated into neighbouring countries, namely, the Grand Duchy of Lithuania and the Kingdom of Hungary and Poland. ${ }^{16}$ In order to emphasize the close ties between modern and old Ukrainian historical periods, Hrushevskyi employed the term of "Ukraine-Rus"17, in addition, his works triggered a total breakaway from "pan-Russian" schemes, by offering a rebuttal of a Russian paradigm claiming that Ukrainians practically played no major role whatsoever in history. On the contrary, according to the historian, their historical roots date back to even earlier times than that of the Russians'.

Ever since 1991, Ukrainian historians and political leaders have paid particular attention to the "legitimization" of their history, the ambition being keenly focused on proving that a Ukrainian state had already existed before. According to the official historical narrative, today's Ukraine must be regarded as the direct successor of the Middle Age's Kievan Rus', the Cossack state established by Bogdan Kmelnytsky and the Ukrainian People's Republic in 1918-1920. ${ }^{18}$ What is more, contemporary Ukrainian historiography emphasizes Ukraine's role as a "bridge"

\footnotetext{
${ }^{15}$ Vely 'ky 'j Ukrayinecz': Materialy' z zhy'ttya i diyal 'nosti Grushevs 'kogo. Veselka, Ky`yiv. 1992. p. 206.

${ }^{16}$ Wynar, L., Mykhailo Hrushevsky: Ukrainian-Russian Confrontation in Historiography. Toronto-New York-Munich 1988. pp. 15-16.

${ }^{17}$ It was Hrushevskyi's university professor, V.A. Antonovich, who introduced the term of "Ukraine-Rus" into political categories.

${ }^{18}$ Sz. Jekelcsik, Ukrajna története- Egy Modern Nemzet születése. Kairosz, Budapest 2014. p. 21.
} 
and having a "civilizational periphery status", which has actually connects and has connected Russia with Europe for centuries.

One cannot fail to highlight official speeches given by former and current presidents of the young Ukrainian state,$^{19}$ in which, for example, Leonid Kuchma describes Bogdan Kmelnytsky as a titanic figure of Ukrainian history - one, who succeeded in elevating Ukraine onto the international stage and laying the foundations of present Ukraine as a political nation..$^{20}$ Moreover, the former Ukrainian president points out that the Ukrainian people are a "large and powerful nation" in the middle of Europe, having played a crucial role in European history on several occasions. In the same line of thinking, we can add contributions made by Viktor Yushchenko, who accentuated Ukraine's relations to Europe primarily from a cultural-historical point of view. In addition, regarding Ukrainian history, he brings values of democracy and freedom to the forefront. ${ }^{21}$ Thus, Ukraine's heads of state have utilized "glorious history" for the creation of a collective historical identity, placing Mykhailo Hrushevskyi's cult in the central focus, who, being the first president of Ukraine, serves as the reasonable basis for legitimizing the present day presidency. However, at the same time, Bogdan Kmelnytsky becomes the "Nation's Father", creator of Ukrainian statehood, historical unity and continuity.

As for the Constitution of Ukraine of 1996, "it is laid upon the historical constitutional traditions of the Ukrainian state ... relying on the centuries of Ukrainian establishment of the state ..."22. Their national anthem titled "Ukraine has not perished yet"23 puts forward Ukrainian history as a perpetual series of efforts for independence, guided by the words of "...there will be a time when we become masters in our own country", and emphasizing the work of many "national heroes", among whom Bogdan Kmelnytsky and Mykhailo Hrushevskyi occupy a very significant place.

On the basis of the above, we can state that the Ukrainian Constitution of 1996, leading politicians of Ukraine, as well as contemporary Ukrainian historiography unequivocally proclaim the paradigm claiming that the Ukrainian people, "relying on the hundreds of years of Ukrainian state establishment"

\footnotetext{
${ }^{19}$ V. Szereda, Történelmi emlékezet Ukrajna elnökeinek hivatalos beszédeiben In: Regio (Kisebbség, Politika, Társadalom) 3. 2007. pp.47-68.

${ }^{20}$ Kuchma L. D. Dopovid na urochy'sty`x zborax z nagody` 400-richchya vid dnya narodzhennya Bogdana Xmel`ny`cz`kogo. In: Ukrayins 'ky'j Istory 'chny'J zhurnal . 1996. 4. p. 3.

${ }^{21}$ V. Szereda, Történelmi emlékezet Ukrajna elnökeinek hivatalos beszédeiben In: Regio (Kisebbség, Politika, Társadalom) 3. 2007. p. 56.

${ }^{22}$ http://ufpp.gov.ua/content/PDF/zakonodavstvo/konstitychiya.pdf -:

${ }^{23}$ http://ukrainbazar.republika.pl/Tryzub/Himn.htm
} 
enforced its right to self-determination upon the establishment of the sovereign Ukraine in 1991. ${ }^{24}$ What is more, a common element shared in speeches given by Ukrainian state politicians ${ }^{25}$ and contemporary Ukrainian historiography ${ }^{26}$ lies in the uniform designation of the 17th century as the beginning of a period marking the point of time from which the development of Ukrainian national identity could be observed. As for the argumentation of Ukrainian historiography, the "Cossack state" (1654-1764) was hardly a fully-fledged state, and only existed only for a short period of time, yet the Hetmanate stood as a paragon of Ukrainian statehood for generations to come.

Therefore, following 1991, Ukrainian historians had to accomplish the task of "shaping" the unitary image of national history utilizing the "mosaic-like" events of the long centuries behind, because creation of a single identity is one of the fundamental instruments in legitimizing power. Yet, despite these national and historical elements, completion of these tasks was made difficult by the lack of a continuous Ukrainian statehood. Nevertheless, we must stress that contemporary Ukrainian historiography has not created history simply "out of nothing", since in their reasoning the continuity linking particular historical periods was ensured by a ceaseless chain of endeavours aimed at the formation of statehood.

After 1991, the "new" historical narrative was introduced in school textbooks by temporarily making the works of Mykhailo Hrushevskyi and Orest Subtelny ${ }^{27}$ take over the role of coursebooks. ${ }^{28}$ Teleology can be highlighted as the main feature of the national narrative, it claiming the main goal of Ukrainian history to be the creation of a Ukrainian nation-state and the portrayal of historical

${ }^{24}$ In the region, Ukraine can be classified as one of the countries having had weak, failing, yet short-lived and disputed statehood on several occasions for a short period of time, nevertheless, full sovereignty was only accomplished in 1991. However, at the time of the establishment of the independent Ukraine, the Ukrainian national identity lay in a delayed state, therefore, it was the young Ukrainian state that actually had to construct the nation, not vica versa. - L. Póti, Ukrajna: a nemzetalkotó állam. In: Nemzeti identitás és külpolitika Közép-és Kelet-Európában. Teleki László Alapítvány, Budapest 2003 p. 297; J. L. Kiss, Nemzeti identitás és külpolitika Közép-és Kelet-Európában. In: Nemzeti identitás és külpolitika Közép-és kelet Európában. Teleki László Alapítvány, Budapest 2003. p. 21.

${ }^{25}$ V. Szereda, Történelmi emlékezet Ukrajna elnökeinek hivatalos beszédeiben In: Regio (Kisebbség, Politika, Társadalom) 2007. 3. . 47-68.

${ }^{26}$ V. Smolij, V. Stepankov, Ukrayins 'ka derzhavna ideya XVII-XVIII stolit'. Problemy ' formuvannya, evolyuciyi, realizaciyi. Al 'ternaty'vy', Ky'yiv 1997. 101-102; Yakovenko, N., Nary's istoriyi seredn 'ovichnoyi ta rann 'omodernoyi Ukrayiny'. Kritika, Kiyiv 2005. pp. 313-314; V. P. Shevchuk, M. G. Taranenko, Istoriya ukrayins 'koyi derzhavnosti. Ly'by’d', Ky’yiv 1999. pp. 94-103.

${ }^{27}$ O. Subtel`ny`j, Ukrayina: istoriya. Liby`d’, Kiyiv 1991.

${ }^{28}$ A. Portnov, Történelemírás ukrán módra. Megjegyzések a hétköznapi valóság történet alapú átrendezéséhez. In: Ukrajna szineváltozása 1991-2008 - Politikai, gazdasági, kulturális és nemzetiségi attitüdök. Szerk.: Fedinec Csilla, Szereda Viktória Kalligram Kiadó, Pozsony 2009. p. 24. 
processes as a path leading to this, that is to say, present-day Ukraine owes its existence to century-long aspirations aimed at the establishment of the modern Ukrainian nation and the achievement of a national homeland. ${ }^{29}$

\section{Divided Ukraine- divided historical remembrance}

Dichotomy, the topmost characteristic of contemporary Ukrainian society and politics must also be emphasized. This partly derives from Ukraine's territorial and language division and the view of claiming that the divide between Eastern and Western Ukraine is so sharp that their separation seems inevitable. ${ }^{30}$ Yet, one must stress that it is in fact the "interpretation of its national history that divides Ukrainians in the first place".

The Ukrainian state formed as a consequence of the dis-integrational processes taking place in the early 1990s, can be regarded as the de jure and de facto successor of the Ukrainian Soviet Socialist Republic. Historical legitimacy, however, appeared as the very first of the problems to come, as did the issue of what should be done with the Soviet past and its symbols. Three typical types of historical remembrance emerged in the three major Ukrainian regions, in Western and South-East Ukraine, and in the central territories.

As regards the East Ukrainians who are closely linked to Russians, and where Ukrainian identity can be seen in a state of "belatedness", the Soviet version of historical remembrance emerged, meaning that they consider their history a part of Russian history, and reject the anti-Russian orientation of their national history, as well as the confrontation of "European Ukraine-Asian Russia". The reason might be that the thesis of Ukraine's de-russification was not made a part of the political leadership's programme, and the Soviet heritage could not be entirely cut out from the "new" historical narrative ${ }^{31}$, due to the fact that Ukrainian regions having been divided for centuries, had evolved into a unitary administrative and political system during the period of the Soviet regime.

However, at the same time in Western-Ukraine, where, compared to eastern regions, a more "developed" national identity had come about within the Polish and Austrian bond, and which territories were only taken-over by the Soviet Union in 1945 , a sovereign historical image independent from the Russian had taken shape.

${ }^{29}$ Sz. Jekelcsik, Ukrajna története - Egy modern nemzet születése. Kairosz Kiadó, Budapest 2014. p. 22.

${ }^{30}$ M. Rjabcsuk, Két Ukrajna In: 2000 Irodalmi és társadalmi havi lap. 2002. p. 9.

${ }^{31}$ A. Portnov, Történelemírás ukrán módra. Megjegyzések a hétköznapi valóság történet alapú átrendezéséhez. In: Ukrajna szineváltozása 1991-2008 - Politikai, gazdasági, kulturális és nemzetiségi attitüdök. Szerk.: Fedinec Csilla, Szereda Viktória. Kalligram Kiadó, Pozsony 2009. p. 17. 
Finally, concerning historical remembrance, the most radical changes took place in the central region of Ukraine, where Russian-speaking intellectuals of Russian culture were forced to, in order to strengthen their position, prove their "Ukraineness".

\section{Bibliography}

- Bantysh-Kamenskij D. N., Istoriya Maloj Rossiyi ot vodvoreniya slavyan v cej strane do unichtozheniya getmanstva. Juzhno-russkoe knigoizd-vo FA. Johanson, Moskva1903.

- Bocskor Medvecz A., Nacionalizmus és történetírás. Az ukrán történelemformálás hatása a nemzetté válás folyamatában. In: Acta Beregsasiensis 2009. VIII. 2. pp. 17-35.

- Glatz F., Regionális történetszemlélet Közép-Kelet-Európában. In: Történelmi Szemle 43 (1-2). 2001. pp. 87-105.

- Jekelcsik, SZ., Ukrajna története- Egy Modern Nemzet születése. Kairosz, Budapest 2014.

- Karamzin, N. M. Istoriya gosudarstva rossiyskogo. The publication of I. Einernling, St. Petersburg 1842-1843.

- Karácsonyi D., A kelet-európai sztyep és a magyar Alföld mint frontier-területek. In: Földrajzi értesitő 2008. LVII. 1-2. füzet pp. 185-211.

- Kiss J. László: Nemzeti identitás és külpolitika Közép-és Kelet-Európában. In: Nemzeti identitás és külpolitika Közép-és kelet Európában. Teleki László Alapítvány, Budapest 2003 pp. 13-32.

- Kony'ssky 'j G., Istoriya Rusov ili Maloy Rossiyi. Universitetskaya tipografiya, Moskva 1846.

- Kuchma L. D. Dopovid` na urochy'sty`x zborax z nagody`400-richchya vid dnya narodzhennya Bogdana Xmel ’ny'cz 'kogo. In: Ukrayins 'ky'j Istory 'chny'J zhurnal . 1996. 4. pp. 3-12.

- Markevitch, N. A., Istoriya Malorossiyi. Tip. Avgusta Semena, Moskva 1842 II.

- Pogodin, M. P., Issledovaniya, zamechanyia i lekciyi o russkoy istoriyi. Universitetskaya tipografiya, Moskva 1856.

- Portnov A., Történelemírás ukrán módra. Megjegyzések a hétköznapi valóság történet alapú átrendezéséhez. In: Ukrajna színeváltozása 1991-2008 - Politikai, gazdasági, kulturális és nemzetiségi attitüdök. Szerk.: Fedinec Csilla, Szereda Viktória. Kalligram Kiadó, Pozsony 2009 pp. 11-49.

- Póti L., Ukrajna: a nemzetalkotó állam. In: Nemzeti identitás és külpolitika Közép-és Kelet-Európában. Teleki László Alapítvány, Budapest 2003. pp. 297-318.;

- Rjabcsuk M.,: Két Ukrajna. In: 2000 Irodalmi és társadalmi havi lap 2002. http:// ketezer.hu/2002/09/mikola-rjabcsuk-ket-ukrajna/

- Smolij V., Stepankov, V., Ukrayins 'ka derzhavna ideya XVII-XVIII stolit'. Problemy' formuvannya, evolyuciyi, realizaciyi. Al’ternaty`vy', Ky`yiv 1997.

- Subtel`ny`j, O., Ukrayina: istoriya. Liby`d’, Kiyiv 1991.

- Szereda V., Történelmi emlékezet Ukrajna elnökeinek hivatalos beszédeiben In: Regio (Kisebbség, Politika, Társadalom) 2007. 3. pp. 47-68. 
- Rigelman, A. I., Letopisnoye povestvovanye o Maloy Rossiyi i jejo narode a kozakakh voobse. Universitetskaya tipografiya, Moskva 1847.

- Ustryalov, N. G., Russkaya istoriya. Tip-ya ekspeditsii zagotovleniya gos., St. Petersburg 1839.

- Varga B., M. Sz. Hrusevszkij, az "ukrán nemzeti történetírás atyja” In: Acta Universitatis. Szegediensis. 134 (2012) pp. 9-21.

- Vely'ky'j Ukrayinecz': Materialy' z zhy'ttya i diyal 'nosti Grushevs 'kogo / Uporyad. i pidgotov. tekstiv ta fotomaterialiv, koment. ta pry`m. A. P. Demy`denka; Redkol. O. T. Gonchar ta in.; Vstup. slovo L. M. Kravchuka; Pislyamova F. P. Shevchenka. Veselka, Ky`yiv1992.

- Wynar, L., Mykhailo Hrushevsky: Ukrainian-Russian Confrontation in Historiography. Toronto-New York-Munich 1988.

- Yakovenko, N., Nary's istoriyi seredn 'ovichnoyi ta rann 'omodernoyi Ukrayiny'. Kritika, Kiyiv 2005.

Summary: This text analyzes the reasons for the formation of a divided Ukrainian historical remembrance. One must stress out that it is in fact the "interpretation of its national history that divides Ukrainians in the first place". As regards the East Ukrainians, being closely linked to Russians, Ukrainian identity can be seen as being continually in a state of "belatedness", hence the Soviet version of historical remembrance emerged. In Western-Ukraine, the territories of which were only taken-over by the Soviet Union in 1945, a sovereign historical image independent to the Russian had taken shape. Finally, in the central region of Ukraine, Russian-speaking intellectuals of Russian culture were forced to, in order to strengthen their position, prove their "Ukraineness".

Keywords: historical remembrance, "divided history", "large and powerful nation", "Ukraine-Rus", "derussification", sovereign historical image, "national history", teleology, the "Cossack state", "Nation's Father", "legitimization" of history, "civilizational periphery status", "pan-Russian" narrative, "political immaturity", sovereign Ukraine, the problem of Ukrainian statehood

\section{Podzielona ukraińska pamięć historyczna}

Streszczenie: Tekst ten analizuje przyczyny powstania podzielonej pamięci historycznej Ukrainy. Należy podkreślić, że tak naprawdę "to właśnie interpretacja historii narodowej dzieli Ukraińców w pierwszej kolejności”. Jeśli chodzi o wschodnich Ukraińców, którzy są ściśle związani z Rosjanami, ukraińska tożsamość może być postrzegana jako nieustannie "spóźniona", stąd wyłoniła się sowiecka wersja pamięci historycznej. Na Ukrainie Zachodniej, której terytoria przejęte zostały przez Związek Radziecki dopiero w 1945 roku, ukształtował się suwerenny, niezależny od Rosjan, historyczny obraz. Wreszcie w centralnym regionie Ukrainy rosyjskojęzyczni intelektualiści kultury rosyjskiej zostali zmuszeni do udowodnienia swojej "ukraińskości" w celu wzmocnienia swojej pozycji.

Słowa kluczowe: pamięć historyczna, "podzielona historia”, "wielki i potężny naród”, "Ukraina -Rus", "derusyfikacja”, suwerenny obraz historyczny, "historia narodowa”, teleologia, "państwo kozackie", "Ojciec narodu”, "legitymizacja” historii, "cywilizacyjny status peryferii", "pan-rosyjska" narracja, "polityczna niedojrzałość", suwerenna Ukraina, problem ukraińskiej państwowości 